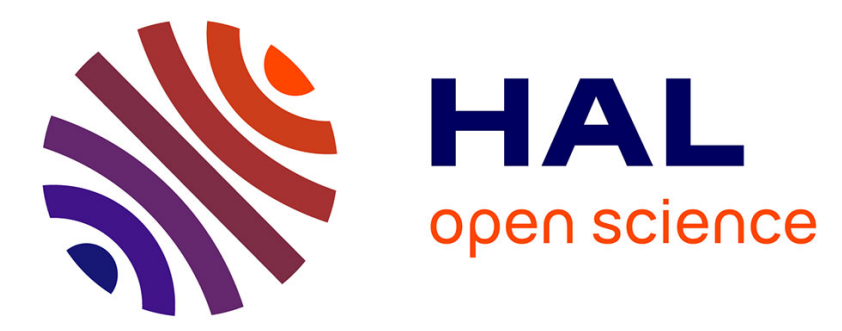

\title{
Actinopolyspora algeriensis sp. nov., a novel halophilic actinomycete isolated from a Saharan soil
}

Atika Meklat, Noureddine Bouras, Abdelghani Zitouni, Florence Mathieu, Ahmed Lebrihi, Peter Schumann, Cathrin Spröer, Hans-Peter Klenk, Nasserdine Sabaou

\section{To cite this version:}

Atika Meklat, Noureddine Bouras, Abdelghani Zitouni, Florence Mathieu, Ahmed Lebrihi, et al.. Actinopolyspora algeriensis sp. nov., a novel halophilic actinomycete isolated from a Saharan soil. Extremophiles, 2012, vol. 16, pp. 771-776. 10.1007/s00792-012-0473-9 . hal-00927627

\section{HAL Id: hal-00927627 https://hal.science/hal-00927627}

Submitted on 13 Jan 2014

HAL is a multi-disciplinary open access archive for the deposit and dissemination of scientific research documents, whether they are published or not. The documents may come from teaching and research institutions in France or abroad, or from public or private research centers.
L'archive ouverte pluridisciplinaire HAL, est destinée au dépôt et à la diffusion de documents scientifiques de niveau recherche, publiés ou non, émanant des établissements d'enseignement et de recherche français ou étrangers, des laboratoires publics ou privés. 


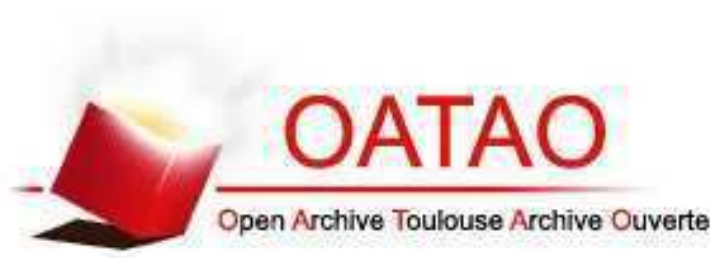

\section{Open Archive Toulouse Archive Ouverte (OATAO)}

OATAO is an open access repository that collects the work of Toulouse researchers and makes it freely available over the web where possible.

This is an author-deposited version published in: http://oatao.univ-toulouse.fr/ Eprints ID: 9996

To link to this article : DOI:10.1007/s00792-012-0473-9

URL: http://dx.doi.org/10.1007/s00792-012-0473-9

\section{To cite this version:}

Meklat, Atika and Bouras, Noureddine and Zitouni, Abdelghani and Mathieu, Florence and Lebrihi, Ahmed and Schumann, Peter and Spröer, Cathrin and Klenk, Hans-Peter and Sabaou, Nasserdine Actinopolyspora algeriensis sp. nov., a novel halophilic actinomycete isolated from a Saharan soil. (2012) Extremophiles, vol. 16 ( $\mathrm{n}^{\circ}$ 5). pp. 771-776. ISSN 1431-0651

Any correspondence concerning this service should be sent to the repository administrator: staff-oatao@listes.diff.inp-toulouse.fr 


\title{
Actinopolyspora algeriensis sp. nov., a novel halophilic actinomycete isolated from a Saharan soil
}

\author{
Atika Meklat - Noureddine Bouras - Abdelghani Zitouni • \\ Florence Mathieu • Ahmed Lebrihi - Peter Schumann • \\ Cathrin Spröer · Hans-Peter Klenk • Nasserdine Sabaou
}

\begin{abstract}
A halophilic actinomycete strain designated $\mathrm{H} 19^{\mathrm{T}}$, was isolated from a Saharan soil in the Bamendil region (Ouargla province, South Algeria) and was characterized taxonomically by using a polyphasic approach. The morphological and chemotaxonomic characteristics of the strain were consistent with those of members of the genus Actinopolyspora, and 16S rRNA gene sequence analysis confirmed that strain $\mathrm{H} 19^{\mathrm{T}}$ was a novel species of the genus Actinopolyspora. DNA-DNA hybridization value between strain $\mathrm{H} 19^{\mathrm{T}}$ and the nearest Actinopolyspora species, A. halophila, was clearly below the $70 \%$ threshold. The genotypic and phenotypic data showed that the organism represents a novel species of the genus Actinopolyspora for which the name Actinopolyspora algeriensis sp. nov. is proposed, with the type strain $\mathrm{H} 19^{\mathrm{T}} \quad$ (= DSM $45476^{\mathrm{T}}=$ CCUG $62415^{\mathrm{T}}$ ).
\end{abstract}

A. Meklat · N. Bouras · A. Zitouni · N. Sabaou ( $\bowtie)$

Laboratoire de Biologie des Systèmes Microbiens (LBSM),

Ecole Normale Supérieure de Kouba, B.P. 92,

16050 Kouba, Alger, Algeria

e-mail: sabaou@yahoo.fr

A. Meklat

e-mail: atika_mek@yahoo.fr

F. Mathieu · A. Lebrihi

Laboratoire de Génie Chimique; UMR 5503 (CNRS/INPT/UPS),

Université de Toulouse; INPT-ENSAT, 1 Avenue de

1'Agrobiopole, BP 32607, Auzeville Tolosane,

31326 Castanet-Tolosan, France

P. Schumann · C. Spröer · H.-P. Klenk

Leibniz Institute DSMZ-German Collection of Microorganisms and Cell Cultures, Inhoffenstraße 7B,

38124 Braunschweig, Germany
Keywords Actinopolyspora algeriensis sp. nov. · Halophilic actinomycete $\cdot$ Saharan soil · Taxonomy

\section{Introduction}

The genus Actinopolyspora was described for the first time by Gochnauer et al. (1975), which represents the only genus in the family Actinopolysporaceae (Zhi et al. 2009). This extremely halophilic genus comprises currently only five species with validly published names, namely A. halophila (Gochnauer et al. 1975), A. mortivallis (Yoshida et al. 1991), A. xinjiangensis (Guan et al. 2010), A. alba and A. erythraea (Tang et al. 2011). The species A. egyptensis was described by Hozzein and Goodfellow (2011), but not yet validated. The strains of this genus were characterized by long chains of spores on aerial mycelium, fragmentation of the substrate mycelium, type IVA cell wall (meso-diaminopimelic acid without glycine, arabinose and galactose as diagnostic whole cell sugars), type PIII (phosphatidylcholine) phospholipid pattern, type 2e fatty acid pattern, and $\mathrm{G}+\mathrm{C}$ contents of the DNA from 64.2 to $68 \mathrm{~mol} \%$ (Gochnauer et al. 1975; Yoshida et al. 1991; Kroppenstedt and Evtushenko 2006). Different predominant menaquinone patterns were reported: MK-6, MK-10 $\left(\mathrm{H}_{4}\right)$, MK-7 and MK-9 $\left(\mathrm{H}_{4}\right)$ for A. xinjiangensis TRM $40136^{\mathrm{T}}$ (Guan et al. 2010), MK-9 $\left(\mathrm{H}_{4}\right)$ and MK-10 $\left(\mathrm{H}_{4}\right)$ for A. alba YIM $90480^{\mathrm{T}}$, A. halophila DSM $43834^{\mathrm{T}}$ and A. mortivallis DSM $44261^{\mathrm{T}}$ (Tang et al. 2011), or MK-9 $\left(\mathrm{H}_{4}\right)$ and MK-9 $\left(\mathrm{H}_{2}\right)$ for A. erythraea (Tang et al. 2011). In this study, a halophilic actinomycete, designated strain $\mathrm{H} 19^{\mathrm{T}}$, was isolated. Based on data from the present polyphasic taxonomic research, this strain is considered to represent a novel species of the genus Actinopolyspora. 


\section{Materials and methods}

\section{Actinomycete strain}

The strain $\mathrm{H} 19^{\mathrm{T}}$ was isolated from a saline soil sample (electrical conductivity $=3.6 \mathrm{mS} \mathrm{cm}^{-1}$ ), collected from Bamendil palm grove (Ouargla province, South Algerian Sahara), by a dilution agar plating method using humic acid-vitamin agar (Hayakawa and Nonomura 1987) supplemented with actidione $\left(50 \mathrm{mg} \mathrm{l}^{-1}\right)$ and $20 \%(\mathrm{w} / \mathrm{v}) \mathrm{NaCl}$ at $30{ }^{\circ} \mathrm{C}$ for 25 days. The strain was purified and maintained at $4{ }^{\circ} \mathrm{C}$ on complex medium (CM) agar (Chun et al. 2000) containing $20 \%$ (w/v) $\mathrm{NaCl}$.

Cultural and micro-morphological characteristics

Cultural characteristics were investigated after 7, 14 and 21 days of incubation at $30^{\circ} \mathrm{C}$ on media from the International Streptomyces Project (ISP 2 and ISP 4) (Shirling and Gottlieb 1966), CM agar (Chun et al. 2000) and nutrient agar (bacteriological peptone, $5 \mathrm{~g}$; meat extract, $1 \mathrm{~g}$; yeast extract, $2 \mathrm{~g}$; $\mathrm{NaCl}, 5 \mathrm{~g}$; agar, $18 \mathrm{~g}$; in $1000 \mathrm{ml}$ deionized water; $\mathrm{pH}$ 7.2). The colours of substrate and aerial mycelia and any soluble pigments produced were determined according to the ISCC-NBS centroid colour chart (Kelly and Judd 1976). The production of melanoid pigments was evaluated on ISP6 and ISP7 media as recommended by Shirling and Gottlieb (1966). Spores and mycelia were examined by light microscope (Motic, B1 Series) and scanning electron microscope (model S450; HITACHI, Japan) after two weeks growth on ISP 2 medium. All media used for morphological characteristics contained $15 \%(\mathrm{w} / \mathrm{v}) \mathrm{NaCl}$.

\section{Physiological characterization}

Several physiological tests were used to characterize the strain $\mathrm{H} 19^{\mathrm{T}}$ in comparison with Actinopolyspora halophila DSM $43834^{\mathrm{T}}$, the most closely related species. Growth and production of acid from carbohydrates, and decarboxylation of organic acids were evaluated using the method of Gordon et al. (1974). Degradation of different other organic compounds was studied as described by Goodfellow (1971). Lysozyme sensitivity and production of nitrate reductase were determined according to the methods of Gordon and Barnett (1977) and Marchal et al. (1987), respectively. Growth at different temperatures, $\mathrm{pH}$ and $\mathrm{NaCl}$ concentrations, and in the presence of antibiotics was determined on nutrient agar medium. All media used for physiological tests contained $15 \%$ (w/v) $\mathrm{NaCl}$ (except for the $\mathrm{NaCl}$ concentration test).

\section{Chemotaxonomic characterization}

For chemotaxonomic analyses, strain $\mathrm{H} 19^{\mathrm{T}}$ was grown in complex medium (CM) broth containing $15 \%$ (w/v) $\mathrm{NaCl}$ at $30{ }^{\circ} \mathrm{C}$ for 10 days on a rotary shaker $(250 \mathrm{rpm})$. Biomass was harvested by centrifugation at $3500 \mathrm{rpm}$ and washed several times with demineralized water. The isomeric form of diaminopimelic acid and the presence (or not) of glycine in the cell wall were realized as described by Becker et al. (1964). The composition of whole-cell sugars was determined as described by Lechevalier and Lechevalier (1970). Phospholipids were analyzed using the procedure of Minnikin et al. (1977). The fatty acid profile was determined by the method of Sasser (1990), using the TSBA40 method on a Microbial Identification System (MIDI) version Sherlock 6.1. The menaquinones were extracted following the procedure of Minnikin et al. (1984), and were analyzed by HPLC (Kroppenstedt 1982, 1985).

Determination of 16S rRNA gene sequence, phylogenetic analysis and DNA-DNA hybridization

The strain $\mathrm{H} 19^{\mathrm{T}}$ was grown on the CM broth supplemented with $15 \%(\mathrm{w} / \mathrm{v}) \mathrm{NaCl}$. Genomic DNA was extracted with DNA extraction kit (JetFlex, Germany). PCR-mediated amplification of the 16S rRNA gene was performed as described by Rainey et al. (1996). PCR products were purified with a PCR product purification kit (Qiagen, Germany). The primers used for sequencing are listed in Coenye et al. (1999). The 16S rRNA sequence has been deposited in the GenBank data library and assigned the accession number HQ918195. The sequences obtained were compared with sequences present in the public sequence databases as well as with the EzTaxon-e server (http://eztaxon-e.ezbiocloud.net/; Kim et al. 2012), a webbased tool for the identification of prokaryotes based on 16S rRNA gene sequences from type strains. Phylogenetic analyses were conducted using MEGA version 5 (Tamura et al. 2011). The $16 \mathrm{~S}$ rRNA gene sequence of the strain $\mathrm{H} 19^{\mathrm{T}}$ was aligned against neighbouring nucleotide sequences using the CLUSTAL W (with default parameters) (Thompson et al. 1994). Phylogenetic tree was constructed by using the neighbour-joining (Saitou and Nei 1987) with Jukes and Cantor (1969) model. Bootstrap analysis (Felsenstein 1985) was performed to evaluate the reliability of the tree topology.

For DNA-DNA hybridizations, cells were disrupted by using a French pressure cell (Thermo Spectronic). The DNA in the crude lysate was purified by chromatography on hydroxyapatite as described by Cashion et al. (1977). DNA-DNA hybridization was carried out as described by De Ley et al. (1970) under consideration of the modifications described by Huss et al. (1983), using a model Cary 
100 Bio UV/VIS-spectrophotometer equipped with a Peltier-thermostatted $6 \times 6$ multicell changer and a temperature controller with in situ temperature probe (Varian). DNA-DNA hybridization experiments were done as duplicates in $2 \times \mathrm{SSC}$ in the presence of $10 \%$ formamide at $71{ }^{\circ} \mathrm{C}$

\section{Results and discussion}

Morphological and biochemical characteristics

Strain $\mathrm{H} 19^{\mathrm{T}}$ exhibited good growth on ISP 2, nutrient agar and CM agar media, and the aerial mycelium was moderately abundant with yellowish white colour on these media. However, no growth was observed on ISP 4 medium. Substrate mycelium was light yellow colour on ISP 2, nutrient agar and CM agar media. Melanoid pigments and other diffusible pigments were not produced on tested media. The substrate mycelium was well developed and fragmented into non-motile rods. The substrate mycelium exhibited an abundant fragmentation on both solid and liquid media. The aerial mycelium was irregularly branched and formed straight to flexuous chains of 10-30 spores per chain. The spores $(0.5-0.6 \times 1.2-1.8 \mu \mathrm{m})$ were non-motile, smooth-surfaced and rod-shaped (Fig. 1). No morphological forms or structures resembling sporangia, sclerotia or synnemata was observed. The strain $\mathrm{H} 19^{\mathrm{T}}$ grew in a wide range of $\mathrm{NaCl}$ concentrations $(7-32 \% \mathrm{w} / \mathrm{v}$ on nutrient agar medium) and was strictly halophilic. It used the majority of sugars and other organic compounds for its

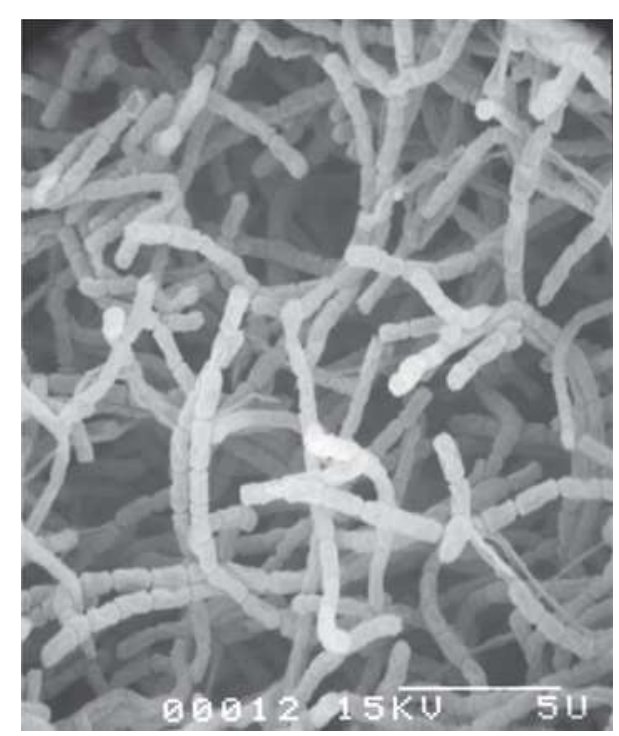

Fig. 1 Scanning electron micrograph of spore chains of strain $\mathrm{H} 19^{\mathrm{T}}$ grown on yeast extract/malt extract agar (ISP 2) containing $15 \%(\mathrm{w} / \mathrm{v})$ $\mathrm{NaCl}$ for 15 days at $30^{\circ}$ C. Bar $5 \mu \mathrm{m}$ growth. It was resistant to some antibiotics tested. The morphological, chemical and physiological characteristics described above are consistent with those of the genus Actinopolyspora. Furthermore, the results showed that the strain $\mathrm{H} 19^{\mathrm{T}}$ is physiologically different from the nearest recognized Actinopolyspora species (A. halophila), as can be seen from the differential physiological characters given in Table 1. The complete physiological characteristics of strain $\mathrm{H} 19^{\mathrm{T}}$ are given in the species description below.

Chemotaxonomic characteristics

Strain $\mathrm{H} 19^{\mathrm{T}}$ contained meso-diaminopimelic acid (but not glycin) in cell wall. Whole-cell hydrolysates contained arabinose and galactose. This is typical of cell wall type IV and whole-cell sugar pattern type A (Lechevalier and Lechevalier 1970). Diagnostic phospholipid detected was phosphatidylcholine, corresponding to phospholipids type PIII (Lechevalier et al. 1977). The predominant fatty acids were anteiso- $\mathrm{C}_{17: 0},(31.3 \%)$, iso- $\mathrm{C}_{15: 0}(17.8 \%)$, anteiso$\mathrm{C}_{15: 0}(15.8 \%)$, iso- $\mathrm{C}_{16: 0}(15.6 \%)$ and iso- $\mathrm{C}_{17: 0}(3.8 \%)$

Table 1 Differential phenotypic characteristics of Actinopolyspora algeriensis sp. nov. compared with the nearest recognized species of the genus A. halophila DSM $43834^{\mathrm{T}}$ Strain: $1, \mathrm{H} 19^{\mathrm{T}} ; 2$, A. halophila DSM $43834^{\mathrm{T}}$

\begin{tabular}{|c|c|c|}
\hline Characteristic & 1 & 2 \\
\hline \multicolumn{3}{|l|}{ Growth and production of acid } \\
\hline D-Cellobiose & + & - \\
\hline D-Galactose & + & - \\
\hline D-Lactose & + & - \\
\hline D-Maltose & + & - \\
\hline D-Mannitol & - & + \\
\hline D-Mannose & + & $-{ }^{\mathrm{a}}$ \\
\hline Salicin & - & $+^{\mathrm{a}}$ \\
\hline D-Glucose & + & $-{ }^{\mathrm{a}}$ \\
\hline Raffinose & + & - \\
\hline Sucrose & + & - \\
\hline D-Xylose & + & - \\
\hline \multicolumn{3}{|l|}{ Decomposition of: } \\
\hline Casein & - & + \\
\hline Hypoxanthine & - & + \\
\hline Production of nitrate reductase & + & - \\
\hline Resistance to erythromycin $\left(10 \mu \mathrm{g} \mathrm{ml}^{-1}\right)$ & - & + \\
\hline Growth at $45^{\circ} \mathrm{C}$ & + & - \\
\hline \multicolumn{3}{|c|}{ Growth on nutrient agar medium in the presence of: } \\
\hline $7 \% \mathrm{NaCl}$ & + & - \\
\hline $32 \% \mathrm{NaCl}$ & + & - \\
\hline
\end{tabular}

+ , positive; -, negative. All data are from the present study

a variable or doubtful results were obtained by Yoshida et al. (1991), Guan et al. (2010), Hozzein and Goodfellow (2011) and Tang et al. (2011) 
(Table 2). This fatty acid pattern belongs to fatty acid type 2e (Kroppenstedt and Evtushenko 2006). The predominant menaquinones were MK-9 $\left(\mathrm{H}_{4}\right)(39.1 \%)$ and MK-10 $\left(\mathrm{H}_{4}\right)$ $(32.1 \%)$. The menaquinones MK-9 $\left(\mathrm{H}_{2}\right)(9.1 \%)$, MK-10 $\left(\mathrm{H}_{2}\right)(5.7 \%)$ and MK-8 $\left(\mathrm{H}_{4}\right)(3.4 \%)$ were also detected.

Phylogenetic analysis based on 16S rRNA gene sequence comparison and DNA-DNA relatedness

The phylogenetic relationship between strain $\mathrm{H} 19^{\mathrm{T}}$ and the other species of Actinopolyspora with validly

Table 2 Cellular fatty acid composition of Actinopolyspora algeriensis strain $\mathrm{H} 19^{\mathrm{T}}$ in comparison with the closely related species $A$. halophila DSM $43834^{\mathrm{T}}$ Taxa: $1, \mathrm{H} 19^{\mathrm{T}} ; 2$, A. halophila DSM $43834^{\mathrm{T}}$ Values are percentages of total fatty acids

\begin{tabular}{|c|c|c|}
\hline Fatty acid & 1 & 2 \\
\hline iso- $\mathrm{C}_{14: 0}$ & 3.4 & 2.4 \\
\hline iso- $\mathrm{C}_{15: 0}$ & 17.8 & 24.1 \\
\hline anteiso- $\mathrm{C}_{15: 0}$ & 15.8 & 34.6 \\
\hline iso- $\mathrm{C}_{16: 1} \mathrm{H}$ & 1.1 & - \\
\hline iso- $\mathrm{C}_{16: 0}$ & 15.6 & 9.3 \\
\hline cis $9-\mathrm{C}_{16: 1}$ & 1.6 & - \\
\hline $\mathrm{C}_{16: 0}$ & 0.5 & 4.7 \\
\hline 9-Methyl-C ${ }_{16: 0}$ & 2.2 & - \\
\hline anteiso- $\mathrm{C}_{17: 1} \mathrm{C}$ & 1.3 & - \\
\hline iso- $\mathrm{C}_{17: 0}$ & 3.8 & 7.4 \\
\hline anteiso- $\mathrm{C}_{17: 0}$ & 31.3 & 10.2 \\
\hline cis $9-\mathrm{C}_{17: 1}$ & 1.3 & - \\
\hline cis $9-\mathrm{C}_{18: 1}$ & 2.7 & 0.6 \\
\hline
\end{tabular}

- not detected

$\mathrm{C}$ and $\mathrm{H}$ indicate that the double bonds are in different locations fatty acid identities were determined by using the TSBA40 method on a Microbial Identification System (MIDI) version Sherlock 6.1 published names is seen in the neighbour-joining dendrogram (Fig. 2). The similarity level was $98.5 \%$ to Actinopolyspora halophila DSM $43834^{\mathrm{T}}$ (Gochnauer et al. 1975), the most closely related species. However, the $16 \mathrm{~S}$ rRNA gene sequence similarities between strain $\mathrm{H} 19^{\mathrm{T}}$ and other remaining Actinopolyspora species were below $97 \%$. DNA of strain $\mathrm{H} 19^{\mathrm{T}}$ was hybridized with that of A. halophila DSM $43834^{\mathrm{T}}$ (Gochnauer et al. 1975), the closest phylogenetic neighbour. The level of DNA-DNA relatedness with this strain was $43.6 \%$ (based on the mean of duplicate determinations, 40.6 and $46.7 \%$ ), which is clearly below the $70 \%$ relatedness guideline proposed by Wayne et al. (1987) for delineation of separate species.

Taxonomic conclusion

The results of the morphological and chemotaxonomic investigations and phylogenetic analysis supported the affiliation of the strain $\mathrm{H} 19^{\mathrm{T}}$ to the genus Actinopolyspora. In addition, a comparison with the physiology of the nearest species $A$. halophila DSM $43834^{\mathrm{T}}$, showed differences in the utilization of casein, hypoxanthine cellobiose, galactose, lactose, maltose, mannitol, mannose and salicin, in the production of nitrate reductase, in the growth at 10 and $20{ }^{\circ} \mathrm{C}$, in the growth with 7 and $32 \% \mathrm{NaCl}(\mathrm{w} / \mathrm{v})$ on nutrient agar medium, and in resistance to erythromycin $\left(10 \mathrm{mg}^{-1}\right)$ as shown in Table 1 . Furthermore, the differences in the production of acids from the utilization of glucose, maltose, raffinose, sucrose and xylose were observed. All of the data support the designation of strain $\mathrm{H} 19^{\mathrm{T}}$ as representing a novel species of the genus Actinopolyspora, for which the name Actinopolyspora algeriensis sp. nov. is proposed.

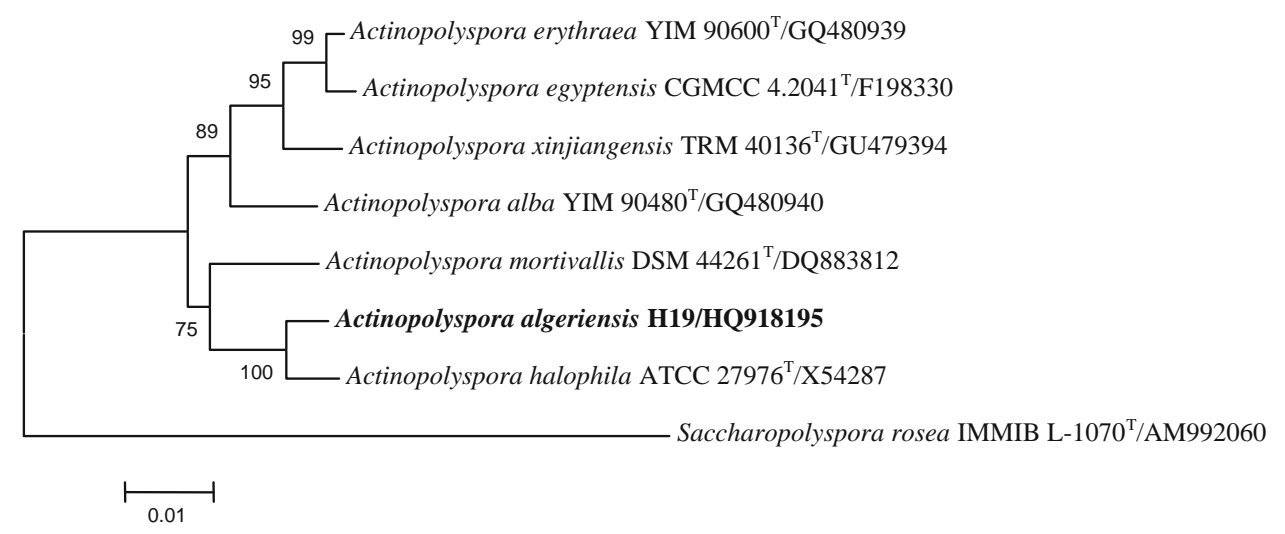

Fig. 2 Phylogenetic tree for species of the genus Actinopolyspora calculated from almost complete 16S rRNA gene sequences using Jukes and Cantor (1969) evolutionary distance methods and the neighbour-joining method of Saitou and Nei (1987). This illustrates the taxonomic position of strain $\mathrm{H} 19^{\mathrm{T}}$ relative to the other species of the genus, including the taxonomically not yet validated A. egyptensis (Hozzein and Goodfellow 2011). Numbers at the nodes are bootstrap values, expressed as a percentage of 1000 resamplings (only values $>50 \%$ are shown). Bar 0.01 nucleotide substitutions per site 
Description of Actinopolyspora algeriensis sp. nov.

Actinopolyspora algeriensis (al.ger.i.en'sis. N.L. fem. adj. algeriensis, pertaining to Algeria, the source of the soil from which the type strain was isolated.

Halophilic filamentous actinomycete, aerial mycelium is yellowish white colour on ISP 2, nutrient agar and CM agar media), and is irregularly branched and formed straight to flexuous chains of 10-30 rod-shaped spores $(0.5-0.6 \times 1.2-1.8 \mu \mathrm{m})$ per chain. The colour of the substrate mycelium is light yellow on all tested culture media. The substrate mycelium was well developed and fragmented into non-motile rods. Melanoid and other diffusible pigments are not produced. Growth occurs at $25,30,35$ and $40{ }^{\circ} \mathrm{C}$ (but not at 10 , 15,20 and $45^{\circ} \mathrm{C}$ ), and $30^{\circ} \mathrm{C}$ is the optimal temperature among the tested ones. Moreover, the growth occurs at $\mathrm{pH} 5,6,7$ and 8 (but not at $\mathrm{pH} 9$ ), and $\mathrm{pH} 7$ is the optimal $\mathrm{pH}$ among the tested ones. Gelatin, guanine and Tween 80 are degraded. Adenine, casein, starch, testosterone, hypoxanthine and xanthine are not decomposed. Utilizes: L-arabinose, D-cellobiose, erythritol, D-fructose, D-galactose, D-glucose, glycerol, maltose, L-rhamnose, D-ribose, adonitol, D-lactose, meso-inositol, D-mannose, D-raffinose, D-trehalose, sucrose and D-xylose as carbon sources for growth and acid production, but not D-mannitol, D-melezitose, melibiose, salicin and D-sorbitol. Acetate, benzoate, butyrate, citrate, oxalate, propionate, pyruvate, succinate and tartrate were not decarboxylated. L-alanine and L-proline are used as source of nitrogen but not L-serine and tyrosine. Nitrate reductase is produced. Growth occurs on nutrient agar medium in the presence of $\mathrm{NaCl}$ at 7, 10, 15, 20, 25, 28, 30 and $32 \%$, but not at 0 and $35 \%(\mathrm{w} / \mathrm{v})$. Moreover, the growth occurs in the presence of kanamycin $\left(5 \mu \mathrm{g} \mathrm{ml}^{-1}\right)$, streptomycin $\left(10 \mu \mathrm{g} \mathrm{ml}^{-1}\right)$ and penicillin $\left(25 \mu \mathrm{g} \mathrm{ml}^{-1}\right)$, and also in the presence of $0.005 \%$ lysozyme, but not in the presence of erythromycin $\left(10 \mu \mathrm{g} \mathrm{ml}^{-1}\right)$ and chloramphenicol $\left(25 \mu \mathrm{g} \mathrm{ml}^{-1}\right.$ ). Type IVA cell wall (meso-diaminopimelic acid, arabinose and galactose in whole-cell hydrolysates). Phospholipids type PIII (phosphatidylcholine). The predominant menaquinones are MK-9 $\left(\mathrm{H}_{4}\right)$ and MK-10 $\left(\mathrm{H}_{4}\right)$. The predominant fatty acids are anteiso- $\mathrm{C}_{17: 0}$, iso- $\mathrm{C}_{15: 0}$, anteiso- $\mathrm{C}_{15: 0}$, iso- $\mathrm{C}_{16: 0}$ and iso- $\mathrm{C}_{17: 0}$.

The type strain is $\mathrm{H}_{19^{\mathrm{T}}}\left(=\mathrm{DSM} 45476^{\mathrm{T}}=\mathrm{CCUG}\right.$ $62415^{\mathrm{T}}$ ) isolated from a Saharan soil sample collected from Ouargla region (South Algeria).

Acknowledgments We would like to gratefully acknowledge the help of Gabriele Pötter (DSMZ) for growing A. algeriensis cultures and for assistance with chemotaxonomical analyses and Bettina Sträubler for assistance with DNA-DNA hybridizations.

\section{References}

Becker B, Lechevalier MP, Gordon RE, Lechevalier HA (1964) Rapid differentiation between Nocardia and Streptomyces by paper chromatography of whole-cell hydrolysates. Appl Microbiol 12:421-423

Cashion P, Hodler-Franklin MA, McCully J, Franklin M (1977) A rapid method for base ratio determination of bacterial DNA. Anal Biochem 81:461-466

Chun J, Bae KS, Moon EY, Jung SO, Lee HK, Kim SJ (2000) Nocardiopsis kunsanensis sp. nov., a moderately halophilic actinomycete isolated from a saltern. Int J Syst Evol Microbiol 50:1909-1913

Coenye T, Falsen E, Vancanneyt M, Hoste B, Govan JR, Kersters K, Vandamme P (1999) Classification of Alcaligenes faecalis-like isolates from the environment and human clinical samples as Ralstonia gilardii sp. nov. Int J Syst Bacteriol 49:405-413

De Ley J, Cattoir H, Reynaerts A (1970) The quantitative measurement of DNA hybridization from renaturation rates. Eur $\mathrm{J}$ Biochem 12:133-142

Felsenstein J (1985) Confidence limits on phylogenies: an approach using the bootstrap. Evolution 39:783-791

Gochnauer MB, Leppard G, Komaratat P, Kates M, Novitsky T, Kushner DJ (1975) Isolation and characterization of Actinopolyspora halophila, gen. et sp. nov., an extremely halophilic actinomycete. Can J Microbiol 21:1500-1511

Goodfellow M (1971) Numerical taxonomy of some nocardioform bacteria. J Gen Microbiol 69:33-90

Gordon RE, Barnett DA (1977) Resistance to rifampicin and lysozyme of strains of some species of Mycobacterium and Nocardia as a taxonomic tool. Int J Syst Bacteriol 27:176-178

Gordon RE, Barnett DA, Handerhan JE, Pang CHN (1974) Nocardia coeliaca, Nocardia autotrophica, and the nocardin strain. Int $\mathrm{J}$ Syst Bacteriol 24:54-63

Guan TW, Liu Y, Zhao K, Xia ZF, Zhang XP, Zhang LL (2010) Actinopolyspora xinjiangensis sp. nov., a novel extremely halophilic actinomycete isolated from a salt lake in Xinjiang, China. Antonie Leeuwenhoek 98:447-453

Hayakawa M, Nonomura H (1987) Humic acid-vitamin agar, a new medium for the selective isolation of soil actinomycetes. J Ferment Technol 65:501-509

Hozzein WN, Goodfellow M (2011) Actinopolyspora egyptensis sp. nov., a new halophilic actinomycete. African J Microbiol Res 5:100-105

Huss VAR, Festl H, Schleifer KH (1983) Studies on the spectrophotometric determination of DNA hybridization from renaturation rates. Syst Appl Microbiol 4:184-192

Jukes TH, Cantor CR (1969) Evolution of protein molecules. In: Munro HN (ed) Mammalian Protein Metabolism. Academic Press, New York, pp 21-132

Kelly KL, Judd DB (1976) Color. Universal Language and Dictionary of Names (National Bureau of Standards Special Publication 440). Washington, DC: US Department of Commerce

Kim OS, Cho YJ, Lee K, Yoon SH, Kim M, Na H, Park SC, Jeon YS, Lee JH, Yi H, Won S, Chun J (2012) Introducing EzTaxon-e: a prokaryotic $16 \mathrm{~S}$ rRNA Gene sequence database with phylotypes that represent uncultured species. Int J Syst Evol Microbiol 62:716-721

Kroppenstedt RM (1982) Separation of bacterial menaquinones by HPLC using reverse phase (RP18) and a silver loaded ion exchanger as stationary phases. J Liq Chromatogr 5:2359-2367

Kroppenstedt RM (1985) Fatty acid and menaquinone analysis of actinomycetes and related organisms. In: Goodfellow M., Minnikin DE (eds) Chemical Methods in Bacterial Systematics, Academic Press, London, pp 173-179 
Kroppenstedt RM, Evtushenko LI (2006) The family Nocardiopsaceae. In: Dworkin M, Falkow S, Rosenberg E, Schleifer KH, Stackebrandt E (eds) The Prokaryotes. A handbook on biology of bacteria, 3rd edn. Springer, New York, pp 754-795

Lechevalier MP, Lechevalier HA (1970) Chemical composition as a criterion in the classification of aerobic actinomycetes. Int J Syst Bacteriol 34:435-444

Lechevalier MP, de Bièvre C, Lechevalier HA (1977) Chemotaxonomy of aerobic actinomycetes: phospholipid composition. Biochem Syst Ecol 5:249-260

Marchal N, Bourdon JL, Richard CL (1987) Les milieux de culture pour l'isolement et l'identification biochimique des bactéries. Doin Press, Paris

Minnikin DE, Patel PV, Alshamaony L, Goodfellow M (1977) Polar lipid composition in the classification of Nocardia and related bacteria. Int J Syst Bacteriol 27:104-107

Minnikin DE, O'Donnell AG, Goodfellow M, Alderson G, Athalye M, Schaal A, Parlett JH (1984) An integrated procedure for the extraction of bacterial isoprenoid quinones and polar lipids. J Microbiol Methods 2:233-241

Rainey FA, Ward-Rainey N, Kroppenstedt RM, Stackebrandt E (1996) The genus Nocardiopsis represents a phylogenetically coherent taxon and a distinct actinomycete lineage: proposal of Nocardiopsaceae fam. nov. Int J Syst Bacteriol 46:1088-1092

Saitou N, Nei M (1987) The neighbor-joining method: a new method for reconstructing phylogenetic trees. Mol Biol Evol 4:406-425

Sasser M (1990) Identification of bacteria by gas chromatography of cellular fatty acids, MIDI Technical Note 101. MIDI Inc., Newark

Shirling EB, Gottlieb D (1966) Methods for characterization of Streptomyces species. Int J Syst Bacteriol 16:313-340
Tamura K, Peterson D, Peterson N, Stecher G, Nei M, Kumar S (2011) MEGA5: molecular evolutionary genetics analysis using maximum likelihood, evolutionary distance, and maximum parsimony methods. Mol Biol Evol 28:2731-2739

Tang SK, Wang Y, Klenk HP, Shi R, Lou K, Zhang YJ, Chen C, Ruan JS, Li WJ (2011) Actinopolyspora alba sp. nov. and Actinopolyspora erythraea sp. nov., isolated from a salt field in China, and reclassification of Actinopolyspora iraqiensis AS $4.1193^{\mathrm{T}}$ (Ruan et al. 1994) as a later heterotypic synonym of Saccharomonospora halophila. Int J Syst Evol Microbiol 61:1693-1698

Thompson JD, Higgins DG, Gibson TJ (1994) CLUSTAL W: improving the sensitivity of progressive multiple sequence alignment through sequence weighting, position-specific gap penalties and weight matrix choice. Nucleic Acids Res 22:4673-4680

Wayne LG, Brenner DJ, Colwell RR, Grimont PAD, Kandler O, Krichevsky MI, Moore LH, Moore WEC, Murray RGE, Stackebrandt E, Starr MP, Trüper HG (1987) International committee on systematic bacteriology. Report of the ad hoc committee on the reconciliation of approaches to bacterial systematic. Int J Syst Bacteriol 37:463-464

Yoshida M, Matsubara K, Kudo T, Horikoshi K (1991) Actinopolyspora mortivallis sp. nov., a moderately halophilic actinomycete. Int J Syst Bacteriol 41:15-20

Zhi X-Y, Li WJ, Stackebrandt E (2009) An update of the structure and 16S rRNA gene sequence-based definition of higher ranks of the class Actinobacteria, with the proposal of two new suborders and four new families and emended descriptions of the existing higher taxa. Int J Syst Evol Microbiol 59:589-608 